\title{
Komunikasi Publik Supporter Bali United Melalui Media Live Streaming Youtube pada Konser Tribun Voice
}

\author{
Muhammad Falah Ramadhan* \\ Fakultas Ilmu Komunikasi, Universitas Islam Bandung, Indonesia. \\ *jhramadhan13@gmail.com
}

\begin{abstract}
This research is motivated by the existence of a virtual concert by Tribun Voice 2020 using YouTube live streaming as the medium. This is done to provide entertainment and enthusiasm for people affected by COVID-19. On the other hand, this was done virtually because of the ban on permits to hold events by inviting large crowds by the Indonesian government. The purpose of this research is to find out the benefits of using YouTube live streaming media today. To uncover this, this research uses a qualitative research method with a case study approach. Live streaming is a symbol of current technological advances that can provide viewing to the wider community without any distance restrictions.
\end{abstract}

Keywords: Live Streaming. Tribune Voice 2020, Public Communication, Case Studies.

\begin{abstract}
Abstrak. Penelitian ini dilatar belakangi oleh adanya konser secara virtual oleh Tribun Voice 2020 dengan menggunakan live streaming youtube sebagai media nya. Hal tersebut dilakukan untuk memberikan hiburan serta semangat bagi masyarakat yang terdampak covid-19. Disisi lain hal tersebut dilakukan secara virtual karena adanya larangan izin untuk membuat acara dengan mengundang masa yang banyak oleh pemerintah Indonesia. Tujuan dilakukannya penelitian ini untuk mengetahui manfaat penggunaan media live streaming youtube saat ini. Untuk membongkar hal tersebut penelitian ini menggunakan metode penelitian kualitatif dengan pendekatan studi kasus. Live streaming menjadi simbol dari kemajuan teknoligi saat ini yang dapat memberikan tontonan kepada masyarakat luas tanpa ada batasan jarak.
\end{abstract}

Kata Kunci: Live Streaming, Tribun Voice 2020, Komunikasi Publik, Studi Kasus. 


\section{A. Pendahuluan}

Tribun Voice adalah sebuah acara rutin yang diselenggarakan oleh komunitas supporter Bali United. Pada awalnya Tribun Voice digelar untuk memperingati hari jadi komunitas supporter Bali United, NorthSideBoys12. Bukan hanya memperingat hari jadi, Tribun Voice sendiri menjadi wadah bagi para anggota komunitas untuk mengekspresikan diri, serta mempererat tali silahturahmi pada setiap anggotanya.

Acara tahunan ini, berawal dari adanya keinginan dari para anggota komunitas untuk membuat event disetiap tahunya, sekaligus untuk memperingati hari jadi komunitas NorthSideBoys 12. Tribun Voice pertama kali diselenggarakan pada tahun 2018, dengan membuat acara kecil-kecilan. Namun, dengan seiring pertumbuhan anggota NorthSideBoys 12 sangat pesat dari tahun ke tahunnya. Tribun Voice semakin dikenal oleh masyarakat luas, khsusunya dikalangan supporter sepakbola Bali United.

Bulan Maret 2020, pemerintah Indonesia secara resmi memerintahkan untuk menghentikan segala bentuk aktivitas yang dilaksanakan diluar rumah dan dianjurkan untuk tidak berkerumun karena adanya penyebaran virus covid-19. Hal itupun berdampak terhadap keberlangsungan acara Tribun Voice. Komunikasi juga merupakan bagian yang tidak terpisahkan dari kehidupan manusia (Onong,2002), karena komunikasi sangat penting untuk interaksi dalam kehidupan manusia Hal ini juga berpengaruh kepada agenda tahunan komunitas NorthSideBoys 12, Tribun Voice. Tribun Voice yang biasanya dilakukan dengan menggelar event musik dengan mengundang massa yang banyak,kini, dengan adanya anjuran pemerintah yang melarang segala aktivitas yang mengundang massa banyak untuk berkerumun demi memutus rantai penyebaran covid-19 di Indonesia. Dengan begitu, acara Tribun Voice 2020 tidak bisa menggelar acara tahunan seperti pada biasanya dengan melibatkan masa yang banyak.

Dengan adanya pandemi covid-19 ini, membuat manusia berkerja lebih untuk memahami dan berusaha beradaptasi dengan kebiasaan baru (new normal). Di era saat ini teknologi tak bisa lepas dari segala aktivitas manusia, hampir seluruh kegiatan manusia telah dikelilingi oleh teknologi yang semakin hari semakin berkembang. Salah satu bentuk dari berkembangnya teknologi media adalah dunia live streaming. Karena jangkauan yang luas dan mudah diakses media Live streaming menjadi pilihan banyak pihak saat ini dalam memberikan informasi serta hiburan selama para penggunanya terhubung dengan jaringan internet.

YouTube adalah salah satu platform yang memiliki fitur live streaming, kini menjadi media yang paling digemari untuk menjadikannya sebagai tempat untuk para user untuk membuat acara-acara dengan berbasis online. Berbeda dengan televisi youtube memiliki fitur live chat untuk para aundice yang bisa melalukan komunikasi kepada user yang menyediakan tanyangannya atau user lainnya.

Melihat hal itu, peneliti tertarik untuk mengungkap peritiwa yang ada dalam konteks masalah ini berangkat dari adanya kasus yang unik karena mengandung unsur-unsur yang berbeda dan belum pernah digunakan konsep live virtual concert ini di Tribun Voice sebelumnya.

Berdasarkan konteks penelitian diatas, peneliti mumutuskan untuk memfokuskan penelitian ini pada bagaimana Komunikasi Publik Supporter Sepakbola Bali United Melali Media Live Streaming Youtube di Konser Tribun Voice 2020.

1. Bagaimana penggunaan media live streaming oleh Tribun Voice 2020?

2. Bagaimana mengelola daya tarik konten live streaming Youtube di Konser Tribun Voice?

3. Mengapa Konser Tribun Voice menggunakan media live streaming di tengah pandemi covid-19?

\section{B. Metodologi Penelitian}

Penelitian ini menggunakan metode penelitian kualitatif. penelitian kualitatif merupakan hal yang penting bagi dasar dari disiplin ilmu khususnya ilmu-ilmu yang mengandung masalah sosial. Selain itu penelitian kualitatif pada hakekatnya merupakan penelitian yang menggunakan pandangan subjektif. Hal tersebut disebabkan, tindakan manusialah yang menentukan sebuah struktur alih-alih struktur menentukan tindakan manusia. Manusia bebas memilih Tindakan apa 
saja dan mereka sebenernya dapat mengubah strukturnya. Mereka menggap bahwa struktur ini hanyalah konstruksi sosial meskipun samar-samar (Mulyana, 2007:35).

Dalam penelitian ini, penulis menggunakan paradigma tipe studi kasus tunggal holistic dan yang menjadi sasaran penelitiannya adalah komunikasi di live concer Tribun Voice 2020. Karena dalam permasalahan ini hanya satu permasalahan saja yang diteliti yaitu bagaimana penggunaan media live streaming dalam konser Tribun Voice 2020.

Studi kasus adalah penelitian yang mengkaji gambaran secara mendetail mengenai latar belakang, karakter yang terdapat dari suatu kasus, dengan memusatkan perhatian kepada suatu kasus secara intensif dan rinci. (Nursalam 2016). Menurut Kartono dan Gulo dalam Suwarma (2015:429) studi kasus atau Case Study merupakan suatu metode pengumpulan data yang bersifat integrative dan comprehensive. Integrative artinya menggunakan berbagai teknik dengan pendekatan yang berbeda dan comprehensive mengumpulkan data secara menyeluruh.

Dalam penelitian ini juga peneliti menggunakan teori parcitipatory, parcitipatory menegaskan bahwa khalayak tidak lagi menjadi objek dari pemilik media tetapi khalayak dapat berperan aktif dalam bermedia, salah satunya dengan cara membuat media live streaming youtube.

\section{Hasil Penelitian dan Pembahasan}

\section{Penggunaan Media Live Streaming Oleh Tribun Voice 2020}

Dengan menggunakan media live streaming, Tribun Voice 2020 ingin pesan-pesan yang disampaikan para teman-teman melalui konser virtual Tribun Voice dapat tersampaikan secara luas. Hal itu menjadi karakteristik dari live streaming itu sendiri, yaitu:

1. Dapat di akses kapan saja dan dimana saja.

2. Siarannya dapat ditonton tanpa ada jarak.

3. Menjadi ajang promosi.

4. Dapat merangsang para penontonya.

Melaui media live streaming Tribun Voice dapat menyebarkan informasi secara luas dan tanpa ada batasan jarak. Hanya saja, dalam menggunakan media live streaming youtube para penonton harus terhubung dengan jaringan internet.

Dalam proses penyiaran melalui live streaming Tribun Voice memiliki divisi-divisi untuk membuat konser virtual ini. Pertama ada divisi acara yang memiliki peran sebagai otak dari jalannya acara, lalu ada divisi kreatif, divisi kreatif memilki tugas untuk membuat gimmick dari konser tersebut atau juga membuat dekorasi secara virtual, dan tim teknis yang mempunyai tanggung jawab untuk mengaplikasikan dari konsep dan layout yang telah disiapkan untuk ditampilkan dalam live streaming konser virtual Tribun Voice 2020.

\section{Mengelola Daya Tarik Konten Live Streaming Youtube di konser Tribun Voice 2020}

Untuk mengelola konten, khsusnya saat acara live streaming di konser virtual Tribun Voice 2020, panitia mempersiapakan tim kreatif di dalamnya. Tim kreatif memiliki peran penting dalam mengelola konten. Baik dalam membantu mengkonsep acara hingga membuat dekorasi secara virtual. Hal itu yang diutarakan narasumber pada saat sesi wawancara dengan peneliti mengenai mengelola daya tarik konten di konser Tribun Voice 2020.

Dalam proses penyiaran melalui live streaming Tribun Voice juga memperhatikan pilarpiliar dari live streaming itu sendiri. Beberapa pilar dari live streaming yang diperhatikan oleh Tribun Voice adalah:

1. Cara pengambilan gambar harus dilakakukan dengan semaksimal mungkin.

2. Suara yang dihasilkan harus terdengar dengan baik.

3. Layout yang tampilan saat live streaming harus menarik perhatian penonton.

4. Pencahayaan yang diberikan harus sesuai agar tayangan menjadi berkualitas.

5. Terhubung dengan jaringan internet yang kuat.

Mengelola live streaming yang tepat dapat membantu menjangkau penonton yang tepat dan mendaptkan kualitas streaming yang baik. Pada proses ini, bukan hanya mendekorasi sebuah acara saja yang menjadi fokus pada live streaming, pemilihan talent juga harus dilakukan dengan tepat. Seorang panitia harus bisa memilih talent seperti apa yang cocok untuk membuat para penonton acara merasa senang dan tidak merasa bosan saat menonton acara live 
streaming Tribun Voice 2020. Adapun yang perlu diperhatikan dalam mengelola daya tarik live streaming:

1. Mengkonsep tema.

2. Membuat dekorasi virtual secara menarik.

3. Pemilihan talent yang tepat.

Untuk menunjang hal tersebut Tribun Voice 2020 memiliki divisi-divisi untuk membuat konser virtual ini.

Pertdivisi acara yang memiliki peran sebagai otak dari jalannya acara, divisi kreatif, divisi kreatif memilki tugas untuk membuat gimmick dari konser tersebut atau juga membuat dekorasi secara virtual.

Dan tim teknis yang mempunyai tanggung jawab untuk mengaplikasikan dari konsep dan layout yang telah disiapkan untuk ditampilkan dalam live streaming konser virtual Tribun Voice 2020.

\section{Alasan Tribun Voice 2020 Menggunakan Media Live Streaming di Tengah Pandemi Covid-} 19

Live Streaming merupakan bidang baru yang menarik untuk dijelajahi karena kemajuan teknologi saat ini membuat semuanya memungkinkan untuk dijelajahi, dengan semakin murahnya peralatan elektronik pendukung live streaming. Saat ini penggunaan layanan live streaming youtube saat sering kali digunakan oleh berbagai pihak baik untuk menjadikannya sebagai sebagai tempat untuk edukasi,hiburan serta menjadi sarana promosi yang dapat bekerja sama dengan pembuat konten dalam sebuah live streaming tersebut.

Hal itupun diungkapkan oleh I Wayan Pasek saat sesi wawancara dengan peneliti "Saat ini hampir semua orang menjadikan youtube sebagai kebutuhan sehari-harinya. Dari sana lah panitia terbesit untuk memanfaatkan media youtube ini, khususnya fitur live streaming youtube ini untuk menjadi alat untuk mempublikasikan event Tribun Voice 2020 dengan jangkuan yang luas".

Berbeda dengan Tribun Voice tahun-tahun sebelumnya Tribun Voice yang menggelar acaranya dengan dilakukan secara offline atau langsung dengan mengundang masa yang banyak, tahun 2020 acara Tribun Voice digelar secara virtual atau menggunakan media live streaming youtube sebagai media nya. Tagline "stay strong and rise together" juga sengaja dibuat untuk memberikan dukungan dan mencoba menghibur masyarakat luas yang mengalami pandemi covid-19 melalui tontonan live streaming.

\section{Kesimpulan}

Berdasarkan pembahasan dalam penelitian ini, peneliti menyimpulkan beberapa hasil penelitian sebagai berikut:

Dalam penggunaan media live streaming,Tribun Voice 2020 memanfaatkan fitur live streaming youtube untuk memberikan tontonan atau hiburan kepada masyarakat luas khususnya masyarakat yang terdampak covid-19.

Pada proses mengelola daya tarik konten live streaming, diperlukan kreatifitas yang tinggi. Bekerja tim sangat diperlukan dalam menentukan ide konten atau dekorasi seperti apa yang ingin digunakan pada saat live streaming berlangsung. Namun, dalam mengelola daya tarik live streaming, tim juga harus bisa menentukan pengisi acaranya. Dengan memilih pengisi acara yang tepat dapat mengikat daya tarik dari live streaming itu sendiri.

Media live streaming youtube adalah media yang sedang tren saat ini. Live streaming youtube saat ini banyak digunakan oleh para instansi atau kelompok dalam menayangkan acaranya dengan cara virtual, begitu juga dengan oleh Tribun Voice 2020 yang menggunakan media live streaming youtube ini sebagai media untuk menayangkan konsernya secara virtual. Hal itu disebabkan adanya larangan dari pemerintah Indonesia terkait untuk menggelar acara dengan mengundang masa yang banyak yang dapat mengakibatkan adanya kerumunan di satu tempat. Tribun Voice 2020 juga memilih media live streaming youtube untuk memberikan semangat atau hiburan kepada masyarakat yang terdampak dari adanya pandemi covid-19. 


\section{Acknowledge}

Terima kasih kepada Allah Swt yang telah memberikan ridho untuk mengerjakan penelitian ini, dan juga kedua orang tua saya serta sahabat-sahabat saya yang tidak pernah berhenti untuk memberi dukungan terhadap penelitian saya ini.

\section{Daftar Pustaka}

[1] Kotler P. Manajemen Pemasaran [Internet]. Jakarta: Indeks; 2005. Available from: Mulyana, Deddy. 2007. Ilmu Komunikasi: Suatu Pengantar. Bandung : Remaja Rosdakarya.

[2] Nursalam. 2016. Metodologi Penelitian Ilmu Keperawatan Pendekatan Praktis Edisi.4. Jakarta : Salemba Medika.

[3] Arni, Muhammad. 2009. Komunikasi Organisasi. Jakarta: Bumi Aksara Rosdakarya 